Limnol. Rev. (2014) 14,3: 153-158

\title{
Monitoring the vitality of Isoëtes lacustris by using a non-destructive method
}

\author{
Margrit Vöge
}

Pergementweg 44b, 22117 Hamburg, Germany, e-mail: isoetes@solo-tauchen.de

\begin{abstract}
The aim of ongoing studies was to expand the non-destructive monitoring of Isoëtes lacustris (Vöge 2004) resulting in a description of the vitality and structure of the population. The influence of the environment on the development of the plant was the subject of extended studies carried out between 1995 and 2014 in more than 100 lakes throughout Europe. The environment was characterized through conductivity, $\mathrm{pH}$ and Secchi depth of the lake water and the accompanying submersed plant species, as well as the plant performance through the mean number of leaves of 20 sporogenous plants. The counting of the leaves was performed whilst diving. The vitality level was defined based on Vöge (2004) and related to the environmental conditions; these are referred to in the context. The inventory of the accompanying plant species may reflect a changing environment. The method is demonstrated through case examples. A highly significant correlation between the mean and the smallest number of leaves of sporogenous plants enables separating juvenile from adult plants. Finally, recent results show a relationship between the vitality level and the structure of the population.
\end{abstract}

Key words: Water quality, mean leaf number, vitality level, population structure

\section{Introduction}

Isoëtes is an ancient cosmopolitan genus of primarily aquatic lycopsids and is phylogenetically isolated from all other living plants (Schuettpelz and Hoot 2006). Many Isoëtes species worldwide are threatened with extinction, as are Isoëtes lacustris and I. echinospora in Central Europe. The species preferably inhabit clear, electrolyte- and nutrient-poor, slightly acid lakes. However, I. echinospora is distinctly less frequent than I. lacustris. Declines in Isoëtes populations are reported largely due to habitat degradation through nutrification of lakes by run-off and drainage from bogs and fertilized farmland. These impacts result in lakes becoming increasingly eutrophicated, acidified or dystrophic. Excessive nutrient loading encourages fast-growing competitive species as well as the development of plankton and epiphytic algae (e.g. Sand-Jensen and Søndergaard 1981; Roelofs et al. 1983; Krause and King 1994; Vöge 1988, 1992; Rintanen 1996; Szmeja 1997; Horn and Petzold 1999; Grzybowski et al. 2008).

The development of quillwort is assumed to be related mainly to lake water data. To what degree the nature of sediment or epiphyte cover on the leaves may influence the plant growth is not clear. To preserve a species knowledge of the population health is necessary. Thus, using a non-destructive technique to evaluate the vitality status of such a perennial longliving species as Isoëtes lacustris is of high importance.

\section{Material and methods}

Selecting the study lakes was random with the aim of assessing the influence of the lake position and environment. According to the preferred habitat conditions of quillwort, data of conductivity (SEC), $\mathrm{pH}$, and Secchi depth proved best suited for describing the aquatic environment. The associating plant species were noted. The leaves per rosette and the spores per megasporangium were counted on 20 plants from a representative population. Megaspore width was measured (spot-checks).The studies were performed as described (Vöge 1997a,b, 2003, 2004).

For demographic studies (unpublished) in the centre of the quillwort populations samples of 800 $\mathrm{cm}^{2}$ were taken at random. These samples were seen as reasonable and necessary for the determination of 
reliable results from very large populations. For each population the leaves of each individual were counted and the existence of developed sporangia was recorded. The lowest number of leaves of a fertile plant was noted and the mean number of leaves of the sporogenous individuals was calculated.

\section{Research area}

Development of a non-destructive monitoring required extended studies in a multitude of lakes with the use of Self-Contained Underwater Breathing Apparatus (SCUBA). They were performed in more than a hundred lakes of Central Europe (Germany, Estonia, Czech Republic), Northern Europe (Denmark, Sweden, Norway, Finland, Iceland) and Western Europe (United Kingdom, Republic of Ireland).

\section{Results and discussion}

Water characteristics and plant data were highly different from one lake to another. The conductivity ranged between 7 and $236 \mu \mathrm{Sm}^{-1}$, $\mathrm{pH}$ was between 5.5 and 8.6, and the range of Secchi depth between 1 and $11 \mathrm{~m}$. The mean number of leaves per rosette was between 6 and 39, the number of spores per megasporangium between 14 and 115 , and the megaspore width between 0.52 and $0.75 \mathrm{~mm}$.

The analysis of the data resulted in a highly significant correlation between mean number of leaves per rosette and mean number of spores per megasporangium. The relationships between the mean number of leaves and conductivity, $\mathrm{pH}$ or Secchi depth were of lower significance (Vöge 1997a,b, 2004). Further studies revealed that the three water characteristics have to be regarded in the context. For example, a higher conductivity value may be balanced by a high value of the Secchi depth.

19 non-isoetid plant species were noted in the study lakes and their nitrogen figure following Ellenberg (1978) may characterize the nutrient situation. Grzybowski et al. (2008) have reported the changing vegetation of lakes, under eutrophication influences; this was accompanied by a decrease in quillwort occurrence in Poland.

\section{Development of the monitoring method}

The monitoring method has been developed following the results of the preliminary studies; it was tested and improved during ongoing research. The ba- sis of the monitoring is the highly significant correlation $(r=0.80)$ between the mean number of spores per megasporangium and the mean number of leaves per rosette:

$\mathrm{MNS}=2.48 \mathrm{MNL}+12.78$,

where: MNS is the mean number of spores per megasporangium, and MNL is the mean number of leaves per plant.

The megaspore number characterizes the vitality of the plant, but their counting is rather laborious and is replaced by counting the leaves instead. Further to this, data of the water quality and the plant species which accompany quillwort are taken into account; their nitrogen figure following Ellenberg (1979) describes their ammonia or nitrate supply.

The vitality level is expressed through the mean number of leaves of 20 sporogenous plants. Wherever in Europe the studies have been performed, quillwort populations with a mean number of leaves over 30 were extremely rare. Accordingly, the highest vitality level is " 3 ". Vitality levels " 2 " or " 1 " represent populations with a mean number of leaves of about 20 or 10 , respectively. The ranges of conductivity, $\mathrm{pH}$ and Secchi depth in which the study populations, described through their vitality level, had occurred are given in Table 1. Vitality level 1 means optimal plant performance in an optimal environment, level 2 is suboptimal performance and environment, while level 3 means low plant performance in a strenuous environment. The level areas overlap sometimes. Accordingly the spore number per megasporangium was $(3)<110$, (2) near $80,(1)<40$. Thus, the vitality level expresses the mean leaf number per rosette in a particular environment.

The studies on lake vegetation have demonstrated that at the early stages of eutrophication elodeid, charid and ceratophyllid plant species thrive in lakes which were originally inhabited exclusively by quillwort and further isoetid species. In these nitrogen-poor sites (vitality level 3), these further isoetid species occurred: I. echinospora, Lobelia dortmanna,

Table 1 . The vitality levels of Isoëtes lacustris related to the ranges of the environmental conditions

\begin{tabular}{cccc}
\hline \multirow{2}{*}{ Vitality level } & $\mathrm{pH}$ & Conductivity & Secchi depth \\
\cline { 3 - 4 } & & {$\left[\mu \mathrm{S} \mathrm{cm}^{-1}\right]$} & {$[\mathrm{m}]$} \\
\hline 3 & $5.5-7.0$ & $7-40$ & $3.7-11.0$ \\
\hline 2 & $6.0-7.5$ & $20-100$ & $2.1-6.0$ \\
\hline 1 & $6.3-8.6$ & $30-238$ & $1.0-4.0$ \\
\hline
\end{tabular}


Littorella uniflora, Ranunculus reptans, Subularia aquatica, and Eriocaulon aquaticum.

Plant species indicating a poor to intermediate nitrogen supply were noted in lakes which were in transition to suboptimal growing conditions for quillwort (level 2): Myriophyllum alterniflorum, Sparganium angustifolium, Potamogeton alpinus, $P$. praelongus, P. gramineus, Elodea canadensis, Nitella flexilis, Chara delicatula, and C. aspera.

Plant species which indicate a rich nitrogen supply or are nitrogen indicators may be observed additionally in sites which are in transition to strenuous growing conditions for quillwort (level 1): Callitriche hamulata, Potamogeton perfoliatus, $P$. crispus, $P$. pectinatus, Myriophyllum spicatum, Ranunculus trichophyllus, R. circinatus, Potamogeton pusillus, P. lucens, and Ceratophyllum demersum.

\section{Application of the method and case examples}

Within a selected population, the leaves of 20 sporogenous rosettes are counted whilst diving and the numbers are noted. The mean number is calculated. One tenth of this number represents the vitality level. Conductivity, $\mathrm{pH}$ and Secchi depth of the lake water are measured. In Figs 1-4 the ranges of the data in which quillwort was found are marked with a vitality level 3 or 2 or 1 . Using the lake data, the corresponding level areas can be read for each parameter at the vertical line. The vitality level and the main three level areas of conductivity, $\mathrm{pH}$ and Secchi depth are compared. Differing results are discussed: reasons may be the balancing of the ecological factors or particular influences. The following four case examples demonstrate the method and the evaluation.

Example 1: Lille Majavatn, Norway: $65^{\circ} 13^{\prime} 54^{\prime \prime} \mathrm{N}$, $013^{\circ} 20^{\prime} 54^{\prime \prime}$. SEC $=33 \mu \mathrm{S} \mathrm{cm}^{-1} ; \mathrm{pH}=6.9$; Secchi depth $=5.9 \mathrm{~m} ; 23$ leaves/rosette, vitality level 2.3. Species: Lobelia dortmanna, Littorella uniflora, Ranunculus reptans, Juncus bulbosus, Myriophyllum alterniflorum, Potamogeton alpinus, and Chara delicatula.

The data of conductivity, $\mathrm{pH}$ and Secchi depth describe optimal to suboptimal growing conditions, which is in accordance with level 2.3. The observed plant species support the result.

Example 2: Lough Corrib, Ireland: 5330'59”N, $009^{\circ} 24^{\prime} 18^{\prime \prime} \mathrm{W}$. SEC $=236 \mu \mathrm{S} \mathrm{cm} \mathrm{cm}^{-1} ; \mathrm{pH}=8.1$; Secchi depth $=4.0 \mathrm{~m} ; 14.5$ leaves/rosette, vitality level 1.5. Species: Lobelia dortmanna, Littorella uniflora, Myriophyl- lum alterniflorum, Elodea canadensis, Chara hispida, C. aspera, Elodea canadensis, Potamogeton gramineus, $P$. praelongus, P. perfoliatus, and P.lucens.

Eutrophication influences in this lake have been reported by Krause and King (1994). The data of conductivity and $\mathrm{pH}$ correspond to strenuous growing conditions; due to the rather high Secchi depth the level is 1.4. The observed plant species reflect the change from oligotrophic to eutrophic lake conditions.

Example 3: Hahellervatnet, Norway: $59^{\circ} 02^{\prime} 03^{\prime \prime} \mathrm{N}$, $007^{\circ} 08^{\prime} 06^{\prime \prime}$. SEC $=7 \mu \mathrm{Cm}^{-1}$; $\mathrm{pH}=5.7$; Secchi depth $=8.0 \mathrm{~m}$; 21 leaves/rosette, vitality level 2.1 .

This lake is situated at $900 \mathrm{~m}$ a.s.l. beyond the birch timber line. All three water characteristics indicate optimal growing conditions, whereas the vitality level is only 2.1, supposedly due to low water temperature. Gacia and Ballesteros (1994) stress that Isoëtes leaf production depends on the water temperature. Further plant species were not found, due to $\mathrm{pH}$ and low conductivity.

Example 4: The unnamed lake in a bog area in Ireland: $54^{\circ} 40^{\prime} 37^{\prime \prime} \mathrm{N}, 008^{\circ} 40^{\prime} 29^{\prime \prime} \mathrm{W}$. SEC $=76 \mu \mathrm{S} \mathrm{cm}{ }^{-1}$; $\mathrm{pH}=6.1$; Secchi depth $=1.3 \mathrm{~m}$; 14 leaves $/$ rosette, vitality level 1.4. Species: Lobelia dortmanna, Littorella uniflora, and Callitriche hamulata.

Situated in an extended bog area, this lake is highly dystrophic. The conductivity value corresponds to suboptimal conditions, the $\mathrm{pH}$ value to optimal growing conditions. Secchi depth is extremely low and indicates strenuous conditions for quillwort, in accordance with the resulting vitality level. The observed plant species suggest that the water transparency has decreased meanwhile. A low Secchi depth means a low water transparency and low light availability for plants. Following Gacia and Ballesteros (1994) low light availability decreases the leaf production. Further to this, the spectral composition of the daylight is changed in dystrophic lakes (Mäkirinta 1978).

The monitoring method is helpful for assessing suspected regional lake impact, such as bathing spots or agricultural effluents. The vitality level was determined at 2.5 in the German Lake Titisee, but 2.0 near a bathing spot. The inclusion of a reasonable plant parameter, as the mean leaf number, appears indispensable for monitoring a plant species. Vlasov (2012) has studied quillwort populations in 12 lakes of Belarus; the frequency of occurrence as plant param- 


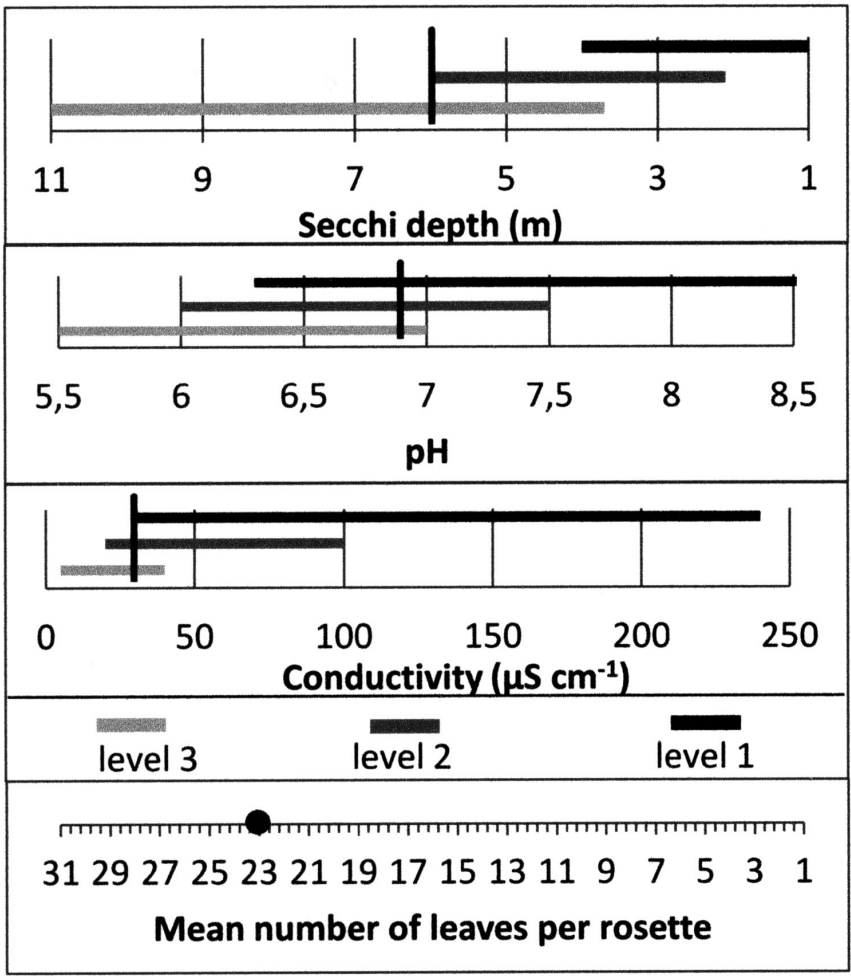

Fig. 1. Example 1, Lille Majavatn

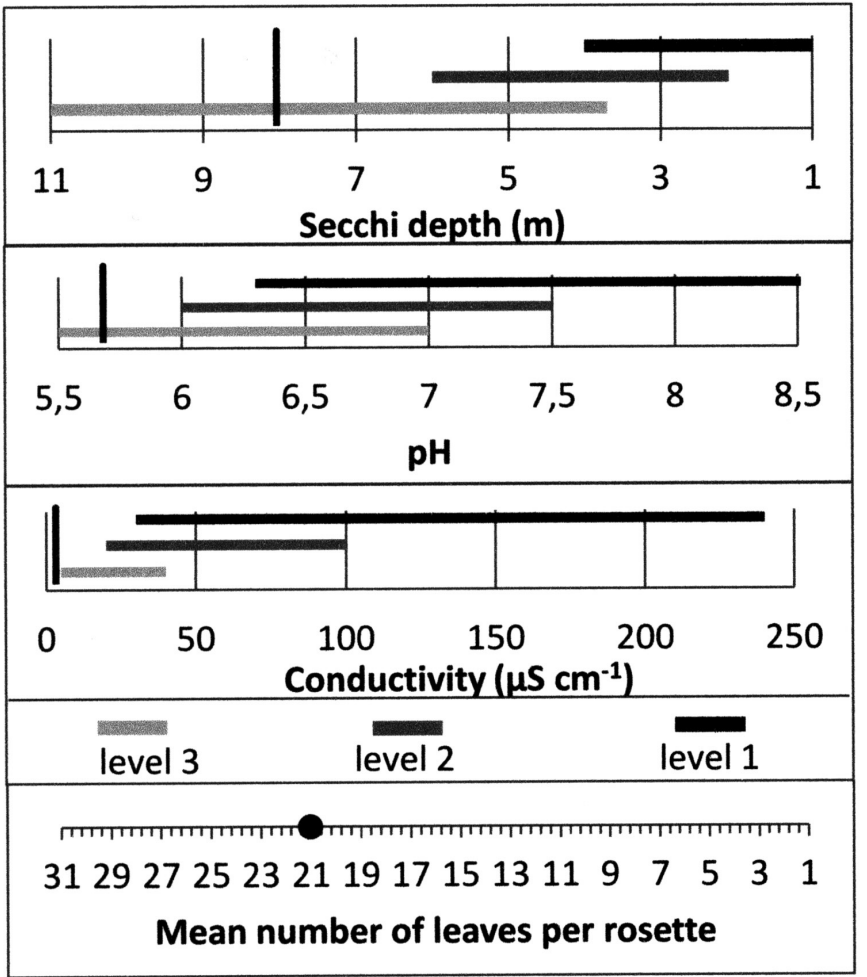

Fig. 3. Example 3, Hahellervatnet

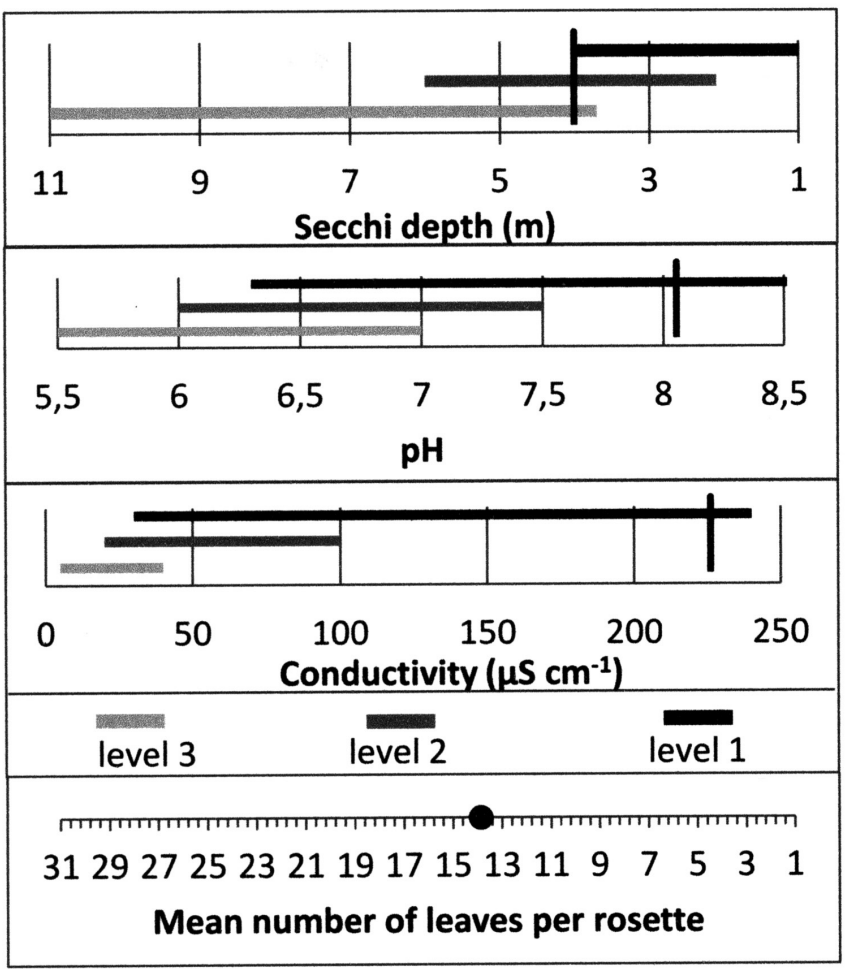

Fig. 2. Example 2, Lough Corrib

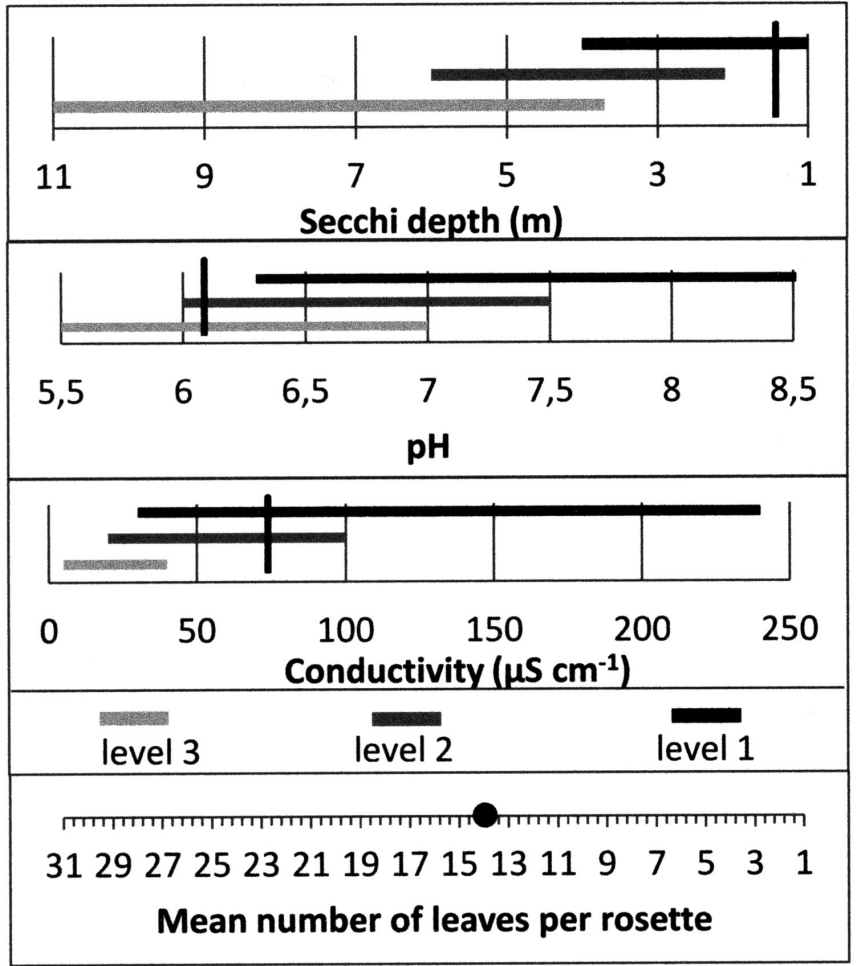

Fig. 4. Example 4, lake in a bog area 
eter proved not to be related to the water quality. The structure of dense populations may differ consisting of numerous small plants or of a low number of large, extended individuals. A dense population was studied in a Norwegian lake. With 7200 plants per square metre it was 10 times the common density of the colonized lake floor of Norwegian sites (Rørslett and Brettum 1989). The vitality level of the few sporogenous plants within the population was 0.6. Independent of the water quality the density stress limited leaf and megaspore numbers.

The Norwegian Lake Svåvatnet is inhabited by both quillwort species. Because they experience the same growing conditions their vitality levels were determined. It was 2.6 for Isoëtes lacustris, and 2.4 for $I$. echinospora, in 2014. From the similarity of the results it may be concluded that the proposed monitoring is useful for both species.
Vitality level and population structure

It was recognized that not all adult plants experiencing suboptimal or strenuous growing conditions produce megaspores. In ongoing research the structure of populations with different vitality levels was studied (unpublished results). A problem was which plants are non-sporogenous because they are juvenile and which ones do not develop megaspores though they are adult? The mean number of leaves and the corresponding smallest leaf number of sporogenous plants proved to be significantly correlated in a multitude of lakes as presented in Fig. 5. Hence, if the mean leaf number is 21 , the smallest leaf number is 14 ; Individuals possessing fewer than 14 leaves are juvenile. Thus, a reliable separation of juvenile and adult individuals could be performed.

The population structure was studied in two sites, one of them in different years. The results are presented in Table 2, together with the correspond-

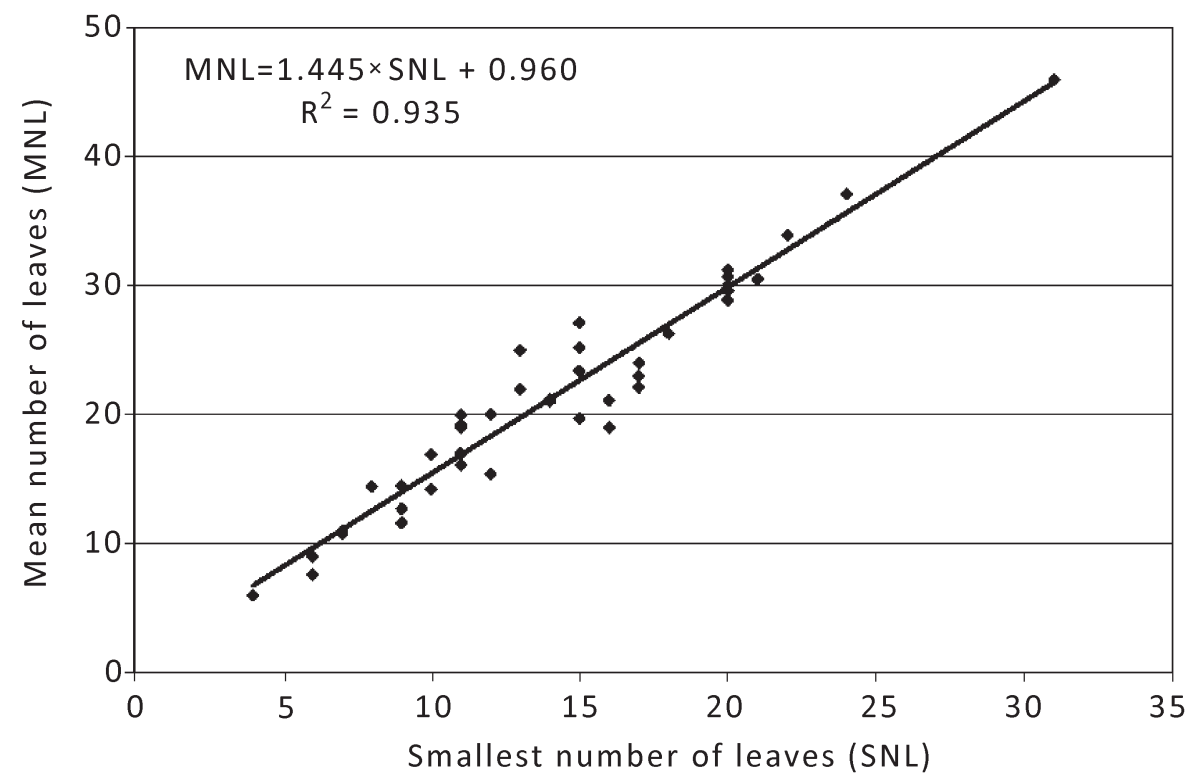

Fig. 5. Relationship between the smallest and the mean number of leaves of fertile plants for quillwort populations from 38 lakes throughout Europe

Table 2. Population structure and vitality level

\begin{tabular}{|c|c|c|c|c|c|}
\hline \multirow[t]{2}{*}{ Site } & \multirow{2}{*}{ Study year } & \multirow{2}{*}{ Position } & \multirow[t]{2}{*}{ Vitality level } & Juvenile plants in the population & $\begin{array}{l}\text { Sporogenous plants in the adult } \\
\text { population }\end{array}$ \\
\hline & & & & {$[\%]$} & [\%] \\
\hline Svåvatnet & 2009 & $\begin{array}{l}58^{\circ} 23^{\prime} 39^{\prime \prime} \mathrm{N} \\
06^{\circ} 05^{\prime} 43^{\prime \prime} \mathrm{E}\end{array}$ & 2.8 & 27 & 84 \\
\hline Svåvatnet & 2014 & $\begin{array}{l}58^{\circ} 23^{\prime} 39^{\prime \prime} \mathrm{N} \\
06^{\circ} 05^{\prime} 43^{\prime \prime} \mathrm{E}\end{array}$ & 2.6 & 21 & 73 \\
\hline Lough Corrib & 1998 & $\begin{array}{l}53^{\circ} 30^{\prime} 59^{\prime \prime} \mathrm{N} \\
09^{\circ} 24^{\prime} 18^{\prime \prime} \mathrm{W}\end{array}$ & 1.4 & 6 & 38 \\
\hline
\end{tabular}


ing vitality level. With decreasing vitality level the percentage of juvenile plants in the population declines; further to this, the percentage of sporogenous plants in the adult population is diminished.

\section{Conclusions}

Isoëtes, the ancient genus, appears not to fit into the modern world changed by man. Quillwort has evolved various adaptations to particular habitats (e.g. Keeley and Busch 1984; Boston and Adams 1987). It does not tolerate competition; this tolerance is not necessary in the particular lakes in which other, competitive plant species cannot thrive. As much as possible should be done for preserving Isoetes lacustris in lakes with suboptimal growing conditions (level 2). Restoration measures on lakes with strenuous growing conditions proved not to be effective. A population on level 1 was often observed to die within a short time. In the German Lake Wollingst the level was 2 in 1986 and diminished to 0.8 within 14 years. Lake restoration measures started and 3 years later the species was found to be extinct (Vöge 2004).

\section{References}

Boston H.L., Adams M.S., 1987, Productivity, growth and photosynthesis of two small "isoëtid" plants, Littorella uniflora and Isoëtes macrospora, J. Ecol. 75: 333-350.

Ellenberg H., 1979, Zeigerwerte der Gefäßpflanzen Mitteleurapas, Scripta. Geobot. 9: 1-122.

Gacia E., Ballesteros,E., 1994, Production of Isoëtes lacustris in a Pyrenean lake: seasonality and ecological factors involved in the growing period, Aquat. Bot. 48: 77-89.

Grzybowski M., Endler Z., Jaworska B., 2008, Disappearance of Isoëtes lacustris localities and changes in the phytolittoral of Lake Długie near Łukta, Limnol. Rev. 8(1-2): 69-77.

Horn K., Paetzold F., 1999, Aktuelle Bestandssituation und Gefährdung des Stachelsporigen Brachsenkrautes (Isoëtes echinospora DURIEU) in Baden-Württemberg, Carolinea 57: 43-56.

Keeley J.E., Busch G., 1984, Carbon assimilation characteristics of the aquatic CAM plant Isoëtes howelli, Plant Physiol. 76: 525-530.

Krause W., King J.J., 1994, The ecological status of Lough Corrib, Ireland, as indicated by physiographic factors, water chemistry and macrophyte flora, Vegetatio 110: 149-161.

Mäkirinta U., 1978, Spektrale Lichtmessungen im freien Wasser und in der Wasservegetation des Sees Kukkia, Südfinnland, unter besonderer Berücksichtigung der Zonation, Aquilo Ser. Bot. 16: 39-53.

Rintanen T., 1996, Changes in the flora and vegetation of 113 Finnish lakes during 40 years, Ann. Bot. Fennici 33: 101-122.

Roelofs J.G.M., Schuurkes J.A.A.R., Smits A.J.M., 1983, Impacts of acidification and eutrophication on macrophyte communities in soft waters. II. Experimental studies, Aquat. Bot. 18: 389-411.

Rørslett B., Brettum P., 1989, The genus Isoëtes in Scandinavia: An ecological review and perspectives, Aquat. Bot. 35: 223-261.

Sand-Jensen K., Søndergaard M., 1981, Phytoplankton and epiphyte development and their shading effect on submerged macrophytes in lakes of different nutrient status, Int. Revue ges. Hydrobiol. 66: 529-552.

Schuettpelz E., Hoot S.B., 2006, Inferring the root of Isoëtes: Exploring alternatives in the absence of an acceptable Outgroup, Syst. Bot. 31: 258-270.

Szmeja J., 1997, Evolution and conservation of Lobelia lake in Poland, Fragm. Flor. Geobot. 42: 89-94.

Vlasov B.P., 2012, Geoecological features of belarus lakes - the habitats of relict species Isoëtes lacustris L., Acta Geogr. Silesiana 12: 57-64.

Vöge M., 1988, Tauchuntersuchungen an der submersen Vegetation in skandinavischen Seen unter besonderer Berücksichtigung der Isoetiden-Vegetation, Limnologica 19(2): 89-107.

Vöge M., 1992, Tauchuntersuchungen an der submersen Vegetation in 13 Seen der Deutschland unter besonderer Berücksichtigung der Isoetiden-Vegetation, Limnologica. 22(1): 82-96.

Vöge M., 1997a, Plant size and fertility of Isoëtes lacustris L. in 20 lakes of Scandinavia: a field study, Arch. Hydrobiol. 139: 171-185.

Vöge M., 1997b, Number of leaves per rosette and fertility characters of the quillwort Isoëtes lacustris L. in 50 lakes of Europe: a field study, Arch. Hydrobiol. 139: 415-431.

Vöge M., 2003, Environmentally related demography: Field studies on Isoëtes lacustris L. (Lycophyta, Isoetaceae) in Europe, [in:] Chandra S., Srivastava M. (eds) Pteridology in the New Millennium, Kluwer Acad. Publ., Dordrecht: 233-260.

Vöge M., 2004, Non-destructive assessing and monitoring of populations of Isoëtes lacustris L., Limnologica 34: 147-153. 